\title{
Identification of Risk Psychosocial Factors as Predictors of Loneliness of Elderly in Nursing Homes During Social Isolation Due to COVID-19 Pandemic
}

\author{
Matej Solićí, Ivona Bulka², Štefica Mikšić ${ }^{3}$, Željko Mudrí ${ }^{3}$, Robert Lovrić ${ }^{3}$, Jelena Jakab ${ }^{3}$, \\ Aleksandar Včev ${ }^{3}$, Mirjana Kralj’3, Jasenka Vujanić ${ }^{3}$ \\ ${ }^{1}$ Home for the Elderly and Infirm, Velika, Croatia \\ ${ }^{2}$ Institutions for Health Care Polyclinic "Intermed", Našice, Croatia \\ ${ }^{3}$ Faculty of Dental Medicine and Health Osijek, Josip Juraj Strossmayer University of Osijek, Osijek, Croatia
}

\begin{abstract}
A B S T R A C T
The elderly is at bigger risk for getting COVID-19 virus, and a particularly vulnerable group are people placed in homes for the elderly and frail. The aims of the study were: (1) to examine differences in the respondent's experiences of social isolation, loneliness and perception of social support, (2) to examine correlations between the dimensions of social isolation and the experience of social support with the experience of loneliness, and (3) to examine whether dimensions of social isolation and perceived social support are risky psychosocial significant predictors of loneliness. The cross-sectional study was conducted on 98 participants from three nursing homes in Croatia, EU. It used Social Provision Scale, the short-form Loneliness Scale and the Multidimensional Scale of Perceived Social Support. The results indicate that people who are single are lonelier, and if they do not have descendants are less likely to contact their family and at the same time they report a weaker social support experience. Loneliness is a statistically positive thing with a social provision dimension, information availability, and a significant negative correlation with the experience of social support. The dimensions of social provision, access to information and perceptions of social support contribute to the experience of loneliness. The constant exposure to negative information about the pandemic, the insecurity and anxiety of the people who communicate with them, make the users of homes for the elderly and infirm even more vulnerable to the development of loneliness.
\end{abstract}

Key words: elderly, COVID-19, pandemics, residential care, nursing home, loneliness, social isolation, social support

\section{Introduction}

The elderly is at bigger risk for getting COVID-19 virus, and a particularly vulnerable group are people placed in homes for the elderly and infirm. Gardner, States and Bagley state that more people in nursing homes live in the same housing, so they are in physical contact on a daily basis, which increases the risk of infection and potentially high mortality from the COVID-19 virus ${ }^{1}$.

Measures of social distancing have proven to be the best way to slow the spread of the virus. Reduced social contacts are expected to increase exposure to stress, which can result in an increased experience of social isolation and loneliness ${ }^{1-3}$. Therefore, people placed in homes during the COVID-19 pandemic are in a special focus because the experience of social isolation can intensify and cause last- ing consequences for psychological health. Given the epidemiological situation caused by COVID-19, it is likely that people placed in nursing homes could react negatively to additional measures of social distancing, as many authors state that in crisis situations, experiences of social isolation, loneliness, depression and lack of social support increase $^{2,4,5}$.

Girdhar, Srivastava and Sethi state that due to social isolation during the COVID-19 pandemic, individuals may additionally feel fear of infection, fear of being hospitalized, fear of being abandoned, or being more concerned for family members ${ }^{6}$. Also, if social isolation lasts for a long period of time, the development of post-traumatic stress or obsessive-compulsive disorder is possible because people wash

Received for publication May 2, 2021 
their hands and disinfect the household more often ${ }^{6}$. Research on the psychological reactions of people during the SARS, H1N1 and Ebola epidemics shows that people show a greater experience of fear of infection and that there is a greater feeling of loneliness, lack of reassurance of worth and depression caused by social distancing ${ }^{7-9}$.

Social isolation and loneliness are related but different concepts. Dury defines social isolation as an individual lack of experience of a sense of belonging and insufficient quality of social engagement in social relationships with other people ${ }^{10}$. It can be a detrimental factor for mental health because it leads to cognitive dysfunction and emotional difficulties such as hopelessness, helplessness, or resignation ${ }^{11}$.

Loneliness, on the other hand, is defined as an unpleasant experience due to a lack of social relationships during a person's major life changes ${ }^{12,13}$. According to Girdhar, in the context of prolonged restrictions and social distance such as occurred during the COVID-19 pandemic, loneliness may become a fundamental component of various psychiatric disorders ${ }^{6}$. On the other hand, an important factor in maintaining social contacts and social networks is social support, which is closely related to social isolation and loneliness ${ }^{10,13}$. Perceived social support is an individual's belief that people will help him in times of need, such as the current crisis due to a pandemic ${ }^{14}$. A specific group of people in the elderly population are those people who are placed in homes for the elderly and infirm. Since nursing homes are institutions, some authors state that such forms of accommodation can further intensify the feeling of social isolation, loneliness, and less sense of social support 2,15

Due to the stated specifics of each mentioned psychological phenomenon in the elderly, it is important to examine whether there were changes in the psychosocial functioning of persons placed in homes for the elderly and infirm during the COVID-19 pandemic.

Therefore, this study had the following aims: (1) examine whether there are differences in the experience of social isolation, loneliness and perception of social support among participants with regard to the frequency of contact with their loved ones, (2) examine the relationship between the dimensions of social isolation and the experience of social support with the experience of loneliness and (3) examine whether the dimensions of social isolation and perception of social support are significant risky psychosocial predictors of loneliness.

\section{Materials and Methods}

\section{Study Design}

A cross-sectional survey was carried out on a suitable sample. The research was conducted from March 27 to 30, 2020 in the Home for the Elderly and the Infirm in Velika and in the Home for the Elderly and the Infirm "Sveti Vinko" in Nova Kapela.

\section{Participants}

The participants in the research were users of homes for the elderly and the infirm. Nursing homes are public institutions founded by the county. The Home for the Elderly and Infirm in Velika is founded by the Požega-Slavonia County, and the Home for the Elderly and Infirm "Sveti Vinko" Nova Kapela is founded by the Brod-Posavina County. A total of 98 participants were included in the study. The accommodation capacity of thehome in Velika is 130 users, of which 83 participated in the research. The accommodation capacity of the in Nova Kapela is 30 users, of which 15 users participated in the research. All participants were over 65 years of age. The criterion for participation in the research was that the participants had preserved cognitive functions and orientation in time and space.

\section{Data Collection}

Participants completed the questionnaire using the pencil-paper method. At the very beginning, the purpose of the research was explained and it was emphasized that the research is anonymous and voluntary and that they can withdraw from participation at any time. The examiner was present during the completion of the questionnaire to assist in case of difficulty in completing the questionnaire. The duration of completing the questionnaire was 15 minutes. All questionnaires were duly completed (all 98) and were used in data processing in the further research process.

\section{Instruments}

The questionnaire used in the study consisted of two parts. The first part consisted of twelve questions about the socio demographic data of the participants. The questionnaire used in the study consisted of two parts. The first part consisted of twelve questions about the socio demographic data of the participants. The second part of the questionnaire consisted of the Social Provision Scale (SPS), the short-form UCLA Loneliness Scale and the Multidimensional Scale of Perceived Social Support (MSPSP). The author's permission was obtained to use the mentioned scales.

The sociodemographic data questionnaire was compiled for the purposes of this research with the aim of examining the demographic characteristics of a selected sample of participants (gender, age, level of education, marital status, descendants). Also, with regard to the objectives of the research, questions were raised about the frequency of contact with persons outside the nursing home before the COVID-19 pandemic and the frequency of contact during the COVID-19 pandemic. It was also checked whether the participants were aware of the fact that a pandemic had occurred and whether they felt protected from the virus in the nursing home and do they use modern forms of communication.

The SPS was used as a measure of experiencing social isolation. This scale was developed by Cutron and Rus- 
sell $^{16}$ based on Weiss's theory of social provision ${ }^{17}$. The scale consists of 24 questions, and the total score is obtained as a linear combination of answers to all questions with a total score of 96 . A score range of 24 to 46 represents social isolation, 47 to 76 an increased risk of experiencing social isolation, and above 76 points means that the person does not feel social isolation, but on the contrary, is fully socialized. The scale consists of six subscales or areas that represent different social functions - Guidance, reassurance of worth, social integration, attachment), reliable alliance and opportunity for nurturance. Deficiency in any of the functions impairs psychological well-being. The overall psychometric properties of the test are quite strong, although the reliability of the test is not entirely satisfactory which is probably due to some metric characteristics of the data collected. The intercorrelations of individual particles in the questionnaire are negative, and the sample on which the test was applied was very homogeneous, which in this case reduced the reliability of the test. A test in previous studies shows Cronbach's Alpha from about 0.83 to 0.92 in the English-speaking area for the scale as a whole ${ }^{18}$.

Loneliness was measured using the short-form UCLA 7-particle scale. The scale is one-dimensional, and the total score is formed as a linear combination of estimates on each of the particles, with a higher score indicating the experience of a higher level of loneliness.

The scale proved to be invariant on different samples of subjects. It was translated into Croatian and psychometric validation was performed by Lacković-Grgin et al ${ }^{19}$. The one-dimensionality of the questionnaire was confirmed, and the reliability of the Cronbach alpha type was $0.83^{19}$.

The MSPSP consists of 12 items, and the translation into Croatian and adaptation was performed by Medved and Keresteš ${ }^{20}$. The result can be expressed as a total score that includes the sum of the responses on all particles and can range from 12 to 84 . A score in the range of 12 to 48 is considered low (low level of perceived social support), a score in the range of 49 to 68 is considered moderate (moderate level of perceived social support], and a score in the range of 69 to 84 is considered high (high level of perceived social support]. The results can also be analyzed through three subscales of four particles. A higher score on a particular subscale indicates a higher level of perceived social support from a particular source of social support - family, friends, significant others. The internal consistency coefficient for the whole scale in previous studies is 0.93 , while the reliability of the three subscales ranges from 0.89 to $0.91^{20,21}$.

\section{Data Analysis}

The collected data examined the existence of differences in social isolation, loneliness and perception of social support from family, friends and significant others with regard to the demographic characteristics of the participants - the frequency of contact with relatives during the
COVID-19 pandemic. Also, the connection between the dimensions of social provision and the experience of social support with the experience of loneliness in the elderly was examined. Ultimately, it was examined whether the dimensions of social provision and the perception of social support were predictors of the experience of loneliness. For this purpose, a descriptive statistical analysis of the data was performed. The study used Pearson's correlation coefficient, one-way analysis of variance and Kruskal Wallis test for comparison of several groups of independent data and hierarchical regression analysis. Prior to data analysis, the assumptions for the justification of the use of parametric data analysis methods were checked.

Using the Kolmogorov-Smirnov (K-S) test of distribution normality, the distribution of measured dimensions was checked, which determined the justification for the use of parametric analyzes on some measured dimensions. Additional checks of distribution normality such as visual inspection of histograms and degrees of asymmetry and flatness were also performed ${ }^{22}$. The variances of some measured dimensions were found to be homogeneous, and a parametric test to compare groups of independent data, a one-way analysis of variance, and a nonparametric test to compare multiple groups of independent Kruskal Wallis data were used to examine differences. The IBM SPSS statistics 18.0 program was used to perform statistical analyzes.

\section{Ethical Considerations}

All participants were informed about the details of the study. Participation in the study was voluntary and participants could withdraw from the study without any consequences. Participants who agreed to the survey signed a consent form to participate in the survey.

Privacy was ensured for each participant during the completion of the questionnaire. Prior to the research, the written consent of the director of the Home for the Elderly and Infirm "Velika" and the Home for the Elderly and Infirm "Sveti Vinko" in Nova Kapela was obtained.

\section{Results}

The structure of the study group is shown in Table 1. The study involved 98 participants, of which 72 were female $(73.5 \%)$ and 26 were male (26.5\%), ranging in age from 61 to 95 years, with an average age $\mathrm{M}=81.86$ years $(\mathrm{SD}=6.40)$.

A descriptive analysis on the basis of the whole sample has been made in order to get the insight on the average values in each individual dimension of the experience of social isolation, loneliness and the perception of social support across the examined sample (Table 2 ).

Mean scores on the social determinant variable indicate that participants in the study are at the higher risk of experiencing social isolation, while a number of participants report more loneliness. The level of perceived social support at the sample level is high. 
TABLE 1

DEMOGRAPHIC DATA OF PARTICIPANTS (N=98)

\begin{tabular}{lc}
\hline \multicolumn{1}{c}{ Education } & $\mathrm{N}(\%)$ \\
\hline Primary school & $74(75.5)$ \\
High school & $14(14.3)$ \\
Higher/university degree & $1(1.0)$ \\
Didn't go to school & $9(9.2)$ \\
Descendants & \\
Children & $6(6.1)$ \\
Children and grandchildren & $76(77.6)$ \\
No descendants & $16(16.3)$ \\
Marital status & \\
Married & $8(8.2)$ \\
Widowed & $83(84.7)$ \\
Divorced & $2(2.0)$ \\
Single & $5(5.1)$ \\
Contact with family prior to COVID-19 pandemic \\
Daily & $42(42.9)$ \\
Once a week & $28(28.6)$ \\
Once a month & $20(20.4)$ \\
2-5 times per year & $5(5.1)$ \\
No contact & $3(3.1)$ \\
Nontact with family during COVID-19 pandemic & $10(10.2)$ \\
Mame as before COVID-19 pandemic & $82(83.7)$ \\
\hline & $6(6.1)$ \\
\hline
\end{tabular}

During the pandemic the use of virtual communication has been introduced via mobile devices and computers (Whatsapp, Viber, Skype, e-mail) in the nursing homes where the survey was conducted. The survey was conducted to examine the extent to which users use such forms of communication and how they rate it, 95 users (96.9\%) stated that they use modern forms of communication, while only 3 users (3.1\%) do not use them. Of those who use 65 participants $(66.3 \%)$ consider this form of communication excellent, and $30(30.6 \%)$ very good, which certainly indicates the possibility of considering this form of contact with their neighbors and in general. Below, users have been questioned about the level of awareness of the COVID-19 virus and about experiencing the fear and protection from it in the nursing home in which they are (Table 3).

At the level of the whole sample. it turned out that almost all participants were aware of the occurrence of coronavirus, citing relatives, media and staff from nursing homes as the most common source of information. Also, participants indicated information exchange with other users of the nursing home in a smaller percentage.

Considering the diversity of sociodemographic characteristics of the participants, and in the interest of the research topic itself, within the first objective it was necessary to examine whether there were differences in the experience of social isolation, loneliness and perceptions of social support considering the frequency of contact with the loved ones. After checking the assumptions for the parametric analysis, it was found that the preconditions for performing the parametric analysis for testing the differences on the two variables - social isolation and loneliness, were met, while the variance was not homogeneous when examining the perception of social support. A oneway analysis of variance and a Kruskal Wallis test (for testing differences in multiple independent result groups) were conducted.

The results of one-way analysis of variance for the social isolation dimension considering the frequency of users contacting with their loved ones during the pandemic showed that there were no differences between groups contacting their loved ones less frequently than before, as usual or more frequently than before the pandemic began $(\mathrm{F}=2.749, P>0.05)$.

TABLE 3

FREQUENCY OF PARTICIPANTS CONSIDERING AWARENESS OF COVID-19 VIRUS

\begin{tabular}{lcc}
\hline \multicolumn{1}{c}{ Parameter } & \multicolumn{2}{c}{ Number (\%) } \\
\cline { 2 - 3 } & Yes & No \\
\hline $\begin{array}{l}\text { Familiarity with the occurrence of } \\
\text { the COVID-19 pandemic }\end{array}$ & $97(99.0)$ & $1(1.0)$ \\
$\begin{array}{l}\text { Situation about infected people in } \\
\text { the county }\end{array}$ & $68(69.4)$ & $30(30.6)$ \\
$\begin{array}{l}\text { Fear of COVID-19 virus } \\
\text { Protection in a nursing home }\end{array}$ & $4(4.1)$ & $94(95.9)$ \\
\hline
\end{tabular}

TABLE 2

DESCRIPTIVE STATISTICS OF THE VARIABLES USED IN THE SURVEY (N=98)

\begin{tabular}{lcccccc}
\hline Variables & M & SD & $P \min$ & $P \max$ & Tmin & Tmax \\
\hline Social isolation & 61.47 & 3.11 & 54 & 72 & 24 & 96 \\
Loneliness & 16.47 & 6.55 & 7 & 32 & 7 & 35 \\
Social support & 69.78 & 9.31 & 35 & 84 & 12 & 84 \\
\hline
\end{tabular}

$M$ - arithmetic mean, $S D$ - standard deviation, $T_{\min }-$ theoretical minimum, $T_{\max }-$ theoretical maximum, $P_{\min }-$ achieved minimum, $P_{\max }-$ achieved maximum, ${ }^{* *} P<0.01,{ }^{*} \mathrm{p}<0.05$. 
There were no statistically significant differences between the groups of subjects in the experience of loneliness $(\mathrm{F}=0.457, P>0.05)$. When examining differences in perceptions of social support (family, friends, significant others), a non-parametric Kruskal-Wallis test was conducted to test the differences in a number of groups. It was found that there were statistically significant differences in perception of social support from families and significant others.

As shown in Table 4. meaning that people who contact their loved ones as often as usual perceive social support from families and significant others higher than those who get in touch less often than before. The same applies to the group contacting more often, however, psychometric characteristics or numerical imbalances of the individual groups in the sample are possible. Also, it can be assumed that although a person contacts his/her relatives more often, the quality of feedback from the interlocutor may not be at the expected level since more frequent contact does not mean better support.
For the purpose of examining the correlation of sociodemographic data, subjective experience of loneliness, measured dimensions of social provision, and perception of social reliable alliance. Pearson's correlation coefficient was analyzed (Table 5). Based on the data in the table, it can be concluded that the correlations range from low to moderate. Results on measured dimensions of social provision (isolation), loneliness and perceptions of social reliable alliance are significantly associated with education, marital status, descendants and frequency of contact with family.

Regarding the measured dimension of loneliness, there was a significant positive correlation with intimate status, indicating that individuals who are single (widowed. divorced or unmarried) experience greater loneliness than individuals who have a partner. Loneliness is statistically significantly related to the dimension of social provision, the guidance, and is significantly negatively correlated with the perception of social support, which means that people who perceive support from the environment as weak also experience a higher level of loneliness.

TABLE 4

RESULTS OF THE KRUSKAL WALLIS TEST TO COMPARE PERCEPTIONS OF SOCIAL SUPPORT PER SUBSCALE CONSIDERING THE FREQUENCY OF CONTACT WITH LOVED ONES DURING COVID-19 PANDEMIC

\begin{tabular}{lccccr}
\hline & \multicolumn{3}{c}{ Median (interquartile range) } \\
\cline { 2 - 4 } & $\begin{array}{c}\text { Not as often as before } \\
\text { COVID-19 pandemic }\end{array}$ & $\begin{array}{c}\text { Same as before } \\
\text { COVID-19 pandemic }\end{array}$ & $\begin{array}{c}\text { More often than before } \\
\text { COVID-19 pandemic }\end{array}$ & P \\
\cline { 2 - 4 } Family & $24.8(24.5-28)$ & $25(24-27)$ & $11.5(5.5-18.5)$ & 0.004 \\
Friends & $23(22-24.5)$ & $24(21-24)$ & $21(18.75-24)$ & 0.285 \\
Significant others & $24(22-26.5)$ & $24(20-26)$ & $19.5(14.75-21.5)$ & 0.049 \\
\hline
\end{tabular}

TABLE 5

CORRELATIONS BETWEEN DEMOGRAPHIC DATA AND 6 MEASURED DIMENSIONS OF SOCIAL PROVISION, LONELINESS AND PERCEIVED SOCIAL SUPPORT

\begin{tabular}{|c|c|c|c|c|c|c|c|c|c|c|c|c|c|}
\hline & 2 & 3 & 4 & 5 & 6 & 7 & 8 & 9 & 10 & 11 & 12 & 13 & 14 \\
\hline 1. Attachment & 0.045 & $0.279 * *$ & $-0.211^{*}$ & -0.039 & -0.153 & -0.173 & -0.049 & 0.129 & -.040 & -0.073 & -0.139 & -0.096 & -.053 \\
\hline 2. Social integration & 1 & -0.088 & $0.263^{*}$ & -0.028 & 0.167 & 0.047 & -0.130 & 0.000 & -.128 & 0.042 & 0.114 & 0.081 & .028 \\
\hline 3. Reassurance of worth & & 1 & $-0.213^{*}$ & 0.076 & -0.154 & 0.039 & 0.089 & 0.049 & -.079 & -0.183 & 0.076 & -0.133 & .002 \\
\hline 4. Reliable alliance & & & 1 & $.212^{*}$ & 0.056 & 0.095 & 0.169 & -0.186 & .033 & -0.003 & 0.059 & 0.157 & -.105 \\
\hline 5. Guidance & & & & 1 & -0.118 & $0.317 * *$ & -0.058 & -0.127 & -.021 & -0.164 & 0.126 & 0.097 & .010 \\
\hline 6. Opportunity for nurturance & & & & & 1 & 0.007 & -0.124 & 0.057 & -.061 & 0.088 & 0.098 & 0.058 & -.008 \\
\hline 7. Loneliness & & & & & & 1 & $-0.293^{* *}$ & -0.170 & .066 & 0.009 & $0.213^{*}$ & 0.143 & .023 \\
\hline 8. Perception of social support & & & & & & & 1 & 0.173 & .076 & $-0.204^{*}$ & $-0.384^{* *}$ & $-0.373^{* *}$ & $-.392^{* *}$ \\
\hline 9. Sex & & & & & & & & 1 & .124 & -0.083 & -0.039 & -0.117 & -.119 \\
\hline 10. Age & & & & & & & & & 1 & 0.033 & -0.115 & -0.012 & -.046 \\
\hline 12. Marital status & & & & & & & & & & & 1 & $0.423 * *$ & .146 \\
\hline 13. Descendants & & & & & & & & & & & & 1 & $.352^{* *}$ \\
\hline 14. Contact with family & & & & & & & & & & & & & 1 \\
\hline
\end{tabular}


Also, a positive correlation between the dimension of perceived social support and education, marital status, descendants and frequency of contact with family was demonstrated. The data indicate that individuals who are single, have no descendants and less frequently contact with family have a lower perception of social support.

The third aim of the study was to investigate whether sociodemographic characteristics, dimensions of social provision and perceptions of social support during the COVID-19 pandemic contribute to experiences of loneliness. A hierarchical regression analysis was performed to determine if there were predictors of loneliness. Before conducting the analysis, itself, the conditions for conducting regression and correlation of predictors and criteria were examined. Model checking revealed no multicollinearity. The Durbin-Watson test value in this model is 1.584 and the residuals can be considered independent. In the first step of the hierarchical regression analysis, the sociodemographic variables were entered, in the second the dimension of social provision, and in the third, the perception of social support. The results obtained are in Table 6.

The results of the hierarchical regression analysis show that the sociodemographic variables do not contribute significantly to the loneliness criterion and explain $8.7 \%$ of the variance of the criteria. The social provision dimensions included in the analysis in the second block explain an additional $9.8 \%$ of the variance. No significant contribution to criterion variance was found, although the dimension "Guidance" was a significant predictor $(B=$ $0.290, P 0.01)$ of loneliness in the sample tested.
In the third block, a social support perception variable was included in the analysis whose contribution to the criterion was statistically significant, and an additional $6.5 \%$ of the variance of loneliness was explained. Guidance $(B=0.261, P<0.05)$ remained a significant predictor, and the perception of social support $(B=0.330, P<0.01)$ was included in the analysis. The results suggest that higher scores on information availability and less experience of social support predict greater levels of loneliness in the participants.

\section{Discussions}

The crisis of the COVID-19 pandemic has spread all over the world, affecting almost all aspects of life, which, among other things, has resulted in an increase in psychological distress. The most vulnerable population are the elderly. Primary prevention for older people with comorbidity involves social distancing and, where possible, social isolation. Elderly living in homes for the elderly and infirm are the most exposed to the consequences of social isolation because the visits are forbidden and they cannot be in physical contact with family members and friends, which further increases the risk of developing negative psychological changes.

The expected contribution of this study was therefore to identify risk factors for the development of negative emotions and states, to examine whether individuals differ from each other in the experience of individual observed variables and to analyze their interrelationship. Ultimately, based on the knowledge gained, try to predict

TABLE 6

RESULTS OF HIERARCHICAL REGRESSION ANALYSIS

\begin{tabular}{lccc}
\hline & Step I & Step II & Step III \\
\hline & $=0.087$ & $=0.185$ & $=0.250$ \\
& $F(6.91)=1.448$ & $F(6.85)=1.708$ & $F(1.84)=7.266^{* *}$ \\
Predictors & & $\Delta 0.098$ & $\Delta$ \\
Sex & -0.176 & $B$ & $B$ \\
Age & 0.111 & -0.133 & -0.079 \\
Education & -0.022 & 0.113 & 0.109 \\
Marital status & 0.204 & 0.035 & 0.002 \\
Descendants & 0.052 & 0.131 & 0.038 \\
Contact with family & -0.037 & 0.058 & 0.006 \\
Attachment & & -0.052 & -0.129 \\
Social integration & & -0.151 & -0.197 \\
Reassurance of worth & & 0.075 & 0.037 \\
Reliable alliance & & 0.077 & 0.123 \\
Guidance & & -0.054 & 0.036 \\
Opportunity for nurturance & & $0.290^{* *}$ & $0.261^{*}$ \\
Perception of social support & & 0.015 & -0.017 \\
\hline
\end{tabular}

$\overline{\mathrm{R}^{2} \text { - the coefficient of multiple determination, } \Delta \mathrm{R}^{2} \text { - increase in coefficient of multiple determination, }}$ $B=$ beta coefficient, ${ }^{* *} P<0.01,{ }^{*} P<0.05$ 
and propose the optimal course of action in homes for the elderly and infirm that would minimize the harmful effects of the current situation on the well-being of the vulnerable group of the elderly.

The results of the research indicate that there are differences in the perception of social support between the participants with regard to the frequency of contact with relatives during the COVID-19 pandemic. People who contacted their families and significant others during the COVID-19 crisis as often as before the crisis reported higher levels of social support. No differences in the experience of social support with regard to friendly relations were found. Research on older people in the community in general often emphasizes the importance of family involvement in the lives of the elderly because such a relationship has a positive impact on the psychosocial well-being of users. Research conducted on people over the age of 65 emphasizes that older people meet their psychological needs mostly in the family circle ${ }^{23}$. Thus, the family is the primary source of support in stressful situations, given that people most often turn to family members or close relatives when they need emotional support because they have more trust in them ${ }^{14,23}$.

Furthermore, the authors of some studies emphasize that significant others, people in the extended family and other close friends who provide a sense of intimacy, security and peace and that lack of contact with these people contributes to the experience of negative feelings and emotional loneliness ${ }^{17,24}$. The fact that there is no difference in the perception of friendly support with regard to the frequency of contact is in line with expectations. Older people generally make friendships with people within the same age group, with similar interests and activities thus reducing negative psychological experiences ${ }^{17,25}$. Nursing home users develop a sense of belonging by socializing and sharing experiences with other users, thus, identifying with the group of people they are surrounded by on a daily basis.

Furthermore, the results indicate that people who are single are lonelier, and if they do not have children and have less contact with their families, they also report a weaker experience of social support. Previous research has shown that people who do not have a sufficient network of social contacts have less support and an increased risk of social isolation and loneliness, which is more common in people living alone without a partner or family members ${ }^{14,26,27}$

Loneliness is statistically significantly positively related to the social provision dimension of information availability and is significantly negatively correlated with the experience of social support. This finding is unexpected because the research mostly states that more frequent contacts and greater guidance reduce the experience of loneliness ${ }^{25,28}$. For example, Drageset in a study suggests the influence of the telephone contact variable on the experience of loneliness ${ }^{25}$. The frequency of contact with loved ones is associated with a lower degree of loneliness because it is assumed that people communicate with those loved ones with whom they share common interests and that they give them support that provides a sense of security, despite geographical distance ${ }^{25}$. Therefore, the negative effect in this study can be explained by the fact that, although people receive more information and also more often during the COVID-19 pandemic, it does not necessarily mean that such information is high quality and empowering. Each person is an individual and experiences the received information in a unique way.

Loneliness is the result of a stressful feeling that accompanies the perception that an individual's needs are not being met by the quality of the relationship ${ }^{29}$. In the case of a measure of social isolation during the COVID-19 virus pandemic, when the physical informal contacts of all nursing home users with people outside the institution are stopped, emotional and social functioning can be disturbed because it is usually maintained by family and friends. Social support, social exchange, and networking are related constructs that can be potent and potentially variable determinants of cognitive health in the elderly population $^{23}$.

Finally, a hierarchical regression analysis was performed in order to respond to the third goal of the study - to check whether, based on certain dimensions of the social provision and the quality of social support experienced, it is possible to predict and prevent the level of loneliness within a given time frame among the users of homes for the elderly and infirm. Different dimensions of social provision and social isolation are associated with health outcomes and mental health ${ }^{30}$. Some researchers state that specific relational provisions may differ among individuals as a result of different factors such as the nature of the stressor or age, and in older age it is an intercorrelation of stressors and life cycle stages ${ }^{17,24,25}$. Given the objective specificities in social interactions during the COVID-19 virus pandemic, it seems important to consider not only the specific circumstances [isolation, limited contact] but also the specifics of a particularly vulnerable group such as the elderly and life in nursing home, in order to correctly identify social needs of users and preserve their psychosocial health. Previous research has repeatedly confirmed a statistically significant interaction of stress and social provisions in predicting mental health ${ }^{16,17,31}$. Studies also indicate that social support is important in performing daily activities for older people living in the community and is closely related to perceived physical and mental health ${ }^{32,33}$. In other words, high social support contributes to the psychological well-being of the individual. That is why social support is included in the consideration of the experience of loneliness in a selected sample during the COVID-19 pandemic.

Hierarchical regression analysis showed that the dimensions of social provision, the guidance and the perception of social support contribute to the experience of loneliness. The guidance includes obtaining advice and exposure to information, both from family and other trusted non-family contacts, which enable action and guide the further behavior of the individual ${ }^{16,17,32}$. The ob- 
tained results, which indicate that a larger amount of information leads to a greater experience of loneliness in the examined sample, are partly unexpected since they indicate data that are contrary to the prevailing opinion. Although research indicates that almost all social provisions are significantly related to loneliness, only the guidance has contributed to the prediction of loneliness, but so that individuals who have more information available report lower levels of loneliness ${ }^{31}$. Coping with stress is better when a person has a wide range of information in the stressful situation in which he finds himself. Social provision theory and findings from previous studies collected on adults suggest that a person will experience psychological discomfort when there is no necessary guidance and information about the event resulting in anxiety and insecurity ${ }^{17,35}$. The cognitive mechanisms of the person receiving the information, as well as the source of the information, are very important. Mancini ${ }^{35}$ states that information from a family or close relative is significantly more associated with positive affect, especially when examining recent experiences. Bearing in mind such data, the explanation of the obtained results can be argued by the fact that contact with the family during the pandemic, which is a current event, is greatly limited and is done exclusively by telephone or video calls. Although such contact is relatively often, it is certainly not identical to ordinary conversations, nor is the quality of the information received encouraging. Although the quantitative adequacy of social contacts and external information is important for meeting different needs and relieving stress, qualitative adequacy is equally important. Too rare, but also, too frequent contacts, as well as insufficient and excessive ones intensify psychological discomfort ${ }^{23,29}$. Relationships with family members in a crisis situation such as a pandemic and isolation are most important to people of this age in order to perceive the situation as less stressful.

However, support providers themselves experience anxiety and insecurity about the situation, so, it is possible that they cause a feeling of helplessness and loneliness in the elderly. Furthermore, it could be concluded that users are overwhelmed with information about an unknown phenomenon through the media. The question arises of the impact of continuous exposure to the media and its negative impact on the psychological state of the elderly. The results suggest that excessive exposure to information can actually have the opposite effect and cause a negative effect in information recipients, and this is where extreme caution should be exercised in approaching the elderly.

On the other hand, regression analysis confirmed the expectation that greater social support reduces the experience of loneliness, which is in line with previous research that has identified a negative correlation between these variables ${ }^{14,23 .}$ Older people who do not receive social support are gradually isolated from society, which could increase the risk of negative consequences for mental health. Routasalo and co-workers conducted a study in
Finland among older people in the community and concluded that the feeling of loneliness among this population is related to the type and quality of social support ${ }^{36}$. They indicate that the feeling of loneliness is not related to the frequency of contact with loved ones, but to the expectations and satisfaction that arise from those contacts. Support from the environment strengthens the psychological dynamics of the individual, provides emotional, and cognitive help that they primarily receive from their family, friends, neighbors and various institutions to be able to deal with their emotional problems.

During the coronavirus pandemic, nursing home workers began to use modern technology more intensively to allow users to communicate with family or friends as easily as possible. It is believed that information and computer technologies can help older people to contact family and friends and prevent isolation and loneliness, which will also make people feel more socially support$\mathrm{ed}^{32}$. A special approach, therefore, should be taken in communication with the elderly regarding the current state of the pandemic and the insecurity that is present in the entire population. It has been shown that home users positively evaluate the use of modern communication technology, which is a motive to continue this practice in the future.

Scientists believe that information and computer technologies can help older people, especially those with reduced mobility, to stay in touch with family and friends, thus, preventing isolation and loneliness, which will make people feel more socially supported ${ }^{32}$. For example, Girdhar, Srivastava, and Sethi cite the results of a study that evaluated a video communication program conducted to facilitate contact between the elderly and family. The data indicate lower levels of loneliness in those older people who used video calls and thus maintained contact with loved ones ${ }^{3,37}$. We can conclude that the way of providing support to older people during the current health crisis could include regular meaningful telephone conversations or video communication to ensure that mental and social needs are met $^{2}$.

Comparison with "the feeling of loneliness of home users" before the pandemic or over an extended time during pandemics are valuable data. According to that, the primary limitation of the study is no existence of longitudinal evaluation. In future research, it would be useful to monitor changes in psychological status in a period when a pandemic crisis like COVID-19 has already become commonplace in life. Since it is not known how much and in which direction the situation with the pandemic will take place, implementation of such research is aggravated. Likewise, in future research, it should equalize the sample according to marital status because marital status as variable effects on results. Also, the measured constructs should be examined with different measuring instruments more appropriate to the target group of respondents. 


\section{Conclusions}

The results of the research indicate that there are differences in the perception of social support between the respondents with regard to the frequency of contact with relatives during the COVID-19 pandemic. People who contacted their families and significant others during the COVID-19 crisis reported higher levels of social support as often as before. No differences in the experience of social support with regard to friendly relations were found. Demographic variables gender, age, previous place of residence, reason for placement in a home and frequency of contact with family were significantly lower to moderately positively related to the dimensions of loneliness and depression. People who are single are lonelier, and if they have no descendants and less frequent contact with family, they also report a weaker experience of social support. Loneliness is significantly positively associated with the dimension of social provision and guidance, and is signifi-

\section{R E F E R E N C E S}

1. GARDNER W, STATES D, BAGLEY N, J Aging Soc Policy, 3 (2020) 1. doi: 10.1080/08959420.2020.1750543. — 2. BROOKS SK, WEBSTER RK, SMITH LE, WOODLAND L, WESSELY S, GREENBERG N, RUBIN GJ, The Lancet, 395 (2020) 912. - 3. QUALTER P, ROTENBERG K, BARRETT L, HENZI P, BARLOW A, STYLIANOU M, REBECCA AH, J Abnorm Child Psychol, 41 (2013) 325. - 4. FULTON JJ, CALHOUN PS, BECKHAM JC, Psychiatry, (2015) 1142. - 5. CACIOPPO JT, HAWKLEY LC, THISTED RA, Psychol Aging, 25 (2010) 453. - 6. GIRDHAR R, SRIVASTAVA V, SETHI S J, Geriatr Care Res, 7 (2020), 29. - 7. SMITH RD, Soc Sci Med, 63 (2006) 3113. - 8. PRATI G, PIETRANTONI L, ZAN B, Risk Anal. 31 (2011) 645. — 9. YANG ZJ, Risk Anal, 36 (2016), 1079. - 10. DURY R, Br J Community Nurs, 19 (2013) 125. - 11. MORLEY JE, VELLAS B, J Nutr Health Aging, 24 (2020) 364. - 12. OKRUSZEK L, ANISZEWSKA-STAŃCZUK A, PIEJKA A, WIŚNIEWSKA M, ŻUREK K, Psy Ar Xiv, (2020) - 13. TILVIS RS, LAITALA V, ROUTASALO PE, PITKÄLÄ KH, J Aging Res, 22 (2011) 534781, doi: 10.4061/2011/534781. — 14. ESKIMEZ Z, DEMIRCI PY, TOSUNOZ IK, OZTUNÇ G, KUMAS G, Int J Caring Sci, 12 (2019) 465. - 15. HOLT-LUNSTAD J, SMITH TB, BAKER M, HARRIS T, STEPHENSON D, Journal of the Association for Psychological Science, 10 (2015) 227. - 16. CUTRONA CE, RUSSELL W, Adv Pers Relation, 1 (1987) 37. - 17. WEISS R, The provisions of social relationships. In: RUBIN Z (Ed): Doing unto others (Prentice Hall, Englewood Cliffs, 1974). - 18. GREEN B, FURRER C, MCALLISTER C, Am J Community Psy- cantly negatively correlated with the experience of social support. The dimension of social provision, the guidance and the perception of social support contribute to the experience of loneliness. Hierarchical regression analysis confirmed the expectation that greater social support reduces the experience of loneliness.

The constant exposure to negative information about the pandemic, the insecurity and anxiety of the people who communicate with them, make the users of homes for the elderly and infirm additionally vulnerable to the development of loneliness.

\section{Acknowledgements}

The authors are especially grateful to all respondents who applied to participate in the research and the Faculty of Dental Medicine and Health Osijek for providing support to our research work. chol, 40 (2007) 96. - 19. LACKOVIĆ-GRGIN K, PENEZIĆ Z, SORIĆ I, Druš Istraž, 7 (1998) 543. - 20. MEDVED A, KERESTEŠ G, Druš Istraž, 2 (2011) 457. - 21. CANTY-MITCHELL J, ZIMET GD, Am J Community Psychol, 28 (2000) 391. — 22. PETZ B, KOLESARIĆ V, IVANEC D, Petz's statistics (Naklada Slap, Jastrebarsko, 2012). - 23. ONI OO, Social support, loneliness and depression in elderly. PhD Thesis. In Canada (Queen's University Kingston, Ontario, 2010). - 24. DRAGESET J, DYS VIK E, ESPEHAUG B, NATVIG GK, FURNES B, Peer J, 3 (2015) 1120. — 25. DRAGESET J, Scand J Caring Sci, 18 (2004) 65. — 26. WENGER CG, Aging Ment Health, 1 (1997) 311. - 27. RYAN AK, WILLITS FK, J Aging Health,19 (2007) 907. - 28. BONDEVIK M, SKOGSTAD A, West J Nurs Res, 20 (1998) 325. doi: 10.1177/019394599802000305. — 29. LIU L, GOU Z, ZUO J, J Health Psychol, 21 (2016) 750. — 30. LANDEIRO F, BARROWS P, MUSSON EN, GRAY AM, LEAL J, BMJ Open, 7 (2017) e013778. doi:10.1136/ bmjopen-2016-013778. - 31. DITOMASSO E, SPINNER B, Pers Individ Dif, 22 (1997) 411. - 32. LITWIN H, J Aging Phys Act, 11 (2003) 389. - 33. GREENGLASS E, FIKSENBAUM L, EATON J, Anxiety Stress Coping, 19 (2006) 15. - 34. WEISS RS, Loneliness, the experience of emotional and social isolation (MIT Press Cambridge, Massachusetts, London, England, 1973). - 35. MANCINI JA, BLIESZNER RJ, Gerontol, 47 (1992) 14. - 36. ROUTASALO P, TILVIS RS, SAVIKKO N, STTRANDBERG TE, Gerontology, 52 (2006) 181. - 37. TSAI HH, TSAI YF, WANG HH, CHANG YC, CHU HH, Aging Ment Health, 14 (2010) 947.

\section{S. Mikšić}

Faculty of Dental Medicine and Health Osijek, Josip Juraj Strossmayer University of Osijek, Crkvena ulica 21, 31000 Osijek, Croatia

e-mail:smiksic@fdmz.hr 


\section{IDENTIFIKACIJA RIZIČNIH PSIHOSOCIJALNIH ČIMBENIKA KAO PREDIKTORA USAMLJENOSTI U SOCIJALNOJ IZOLACIJI KOD STARIJIH OSOBA SMJEŠTENIH U DOMOVE ZA STARIJE I NEMOĆNE TIJEKOM PANDEMIJE BOLESTI COVID - 19}

\section{S A Ž E T A K}

Starije su osobe sklonije obolijevanju od COVID-19 virusa, a posebice vulnerabilna skupina su osobe smještene u domove za starije i nemoćne osobe. Ciljevi ove studije bili su: (1) ispitati postojanje razlika u doživljaju socijalne izolacije, usamljenosti i percepciji socijalne podrške, (2) ispitati povezanost dimenzija socijalne izolacije i doživljaja socijalne podrške s doživljajem usamljenosti i (3) ispitati jesu li dimenzije socijalne izolacije i percepcija socijalne podrške rizični psihosocijalni značajni prediktori doživljaja usamljenosti. Provedeno je presječno istraživanje na 98 sudionika iz tri doma za starije i nemoćne u Hrvatskoj, EU. U ovoj studiji korištene su Skala za procjenu socijalne odredbe, Kratka forme skale usamljenosti i Multidimenzionalna skala percipirane socijalne podrške. Rezultati ukazuju na podatak kako su osobe koje su samci usamljenije, a ukoliko nemaju potomstva I rjeđe kontaktiraju s obitelji, izvještavaju o slabijem doživljaju socijalne podrške. Postoje razlike u percepciji socijalne podrške između ispitivanih osoba s obzirom na učestalost kontaktiranja s bližnjima tijekom trajanja pandemije COVID-19. Rezultati upućuju na podatak kako su osobe koje su samci usamljenije, a ukoliko nemaju potomstva i rjeđe kontaktiraju s obitelji ujedno izvještavaju o slabijem doživljaju socijalne podrške. Usamljenost je statistički značajno pozitivno povezana s dimenzijom socijalne odredbe, dostupnosti informacija i u značajnoj je negativnoj korelaciji s doživljajem socijalne podrške. Dimenzije socijalne zaštite, pristup informacijama i percepcija socijalne potpore doprinose iskustvu usamljenosti. Stalna izloženost negativnim informacijama o pandemiji, nesigurnost i tjeskoba ljudi koji s njima komuniciraju, čine korisnike domova za starije I nemoćne osobe još ranjivijima na razvoj samoće. 